\title{
EFFECTIVENESS OF COPPER CHROME ARSENATE AND USED ENGINE OIL IN PROTECTING FENCING POSTS OF UGANDAN GROWN EUCALYPT CLONE GC550 AND Phoenix reclinata AGAINST TERMITE ATTACK
}

\author{
P. Mugabi ${ }^{1, \star}$ E. Otuko ${ }^{1}$
}

\begin{abstract}
Eucalypts and Phoenix reclinata posts are the most commonly used species for fencing posts in urban areas of Uganda. Although eucalypts are known to be susceptible to termites, fencing posts are still used untreated. In this study, the effectiveness of Copper Chrome Arsenate and used engine oil in protecting Ugandan grown Eucalyptus grandis $\times$ Eucalyptus camaldulensis clone and Phoenix reclinata fencing posts against termite attack were assessed. The objectives were to determine (i) the incidence and (ii) severity of termite attack on Eucalyptus grandis $\times$ Eucalyptus camaldulensis and Phoenix reclinata fencing posts treated with Copper Chrome Arsenate or used engine oil. Ninety $2 \mathrm{ft}$ long samples of Eucalyptus grandis $\times$ Eucalyptus camaldulensis and $P$. reclinata posts were treated with Copper Chrome Arsenate or used engine and others left to act as control then buried in $1 \mathrm{ft}$ deep pits in the ground at a spacing of $1 \mathrm{~m}$ by 1 in Eastern Uganda. The samples were visually inspected monthly for termite damage for 9 months. More than $80 \%$ of untreated samples of both species had been attacked by termites within the first month. Copper Chrome Arsenate treated Eucalyptus grandis $\times$ Eucalyptus camaldulensis and Phoenix reclinata samples were first attacked in the $8^{\text {th }}$ and $5^{\text {th }}$ months respectively. While used engine oil treated Eucalyptus grandis $\times$ Eucalyptus camaldulensis and Phoenix reclinata samples were first attacked in the $7^{\text {th }}$ and $5^{\text {th }}$ months respectively. The modal severity for samples of both species treated with either Copper Chrome Arsenate or used engine oil was class 1 (less than $1 \%$ of the sample volume eaten) while for the untreated samples it was class 5 (above $60 \%$ volume eaten) for the 9 months of field exposure. It was concluded that untreated posts of Eucalyptus grandis $\times$ Eucalyptus camaldulensis and Phoenix reclinata were highly susceptible to termite attack and that the protection offered by used engine oil or Copper Chrome Arsenate managed to restrict damage by termites to only less than $1 \%$ of the sample volume, over the 9 months of exposure for most of the sample posts. It is recommended that the experiment be repeated for a much longer period in order to ascertain the exact service life of the posts under these circumstances. Penetration and retentions of the preservatives in the posts should also be studied in order to ascertain their effect on the efficacy.
\end{abstract}

Keywords: Incidence, severity, treated posts, wood preservation, wood protection.

\section{INTRODUCTION}

The need to improve quality of timber as well as shorten the rotation of trees has led to the development of a number of fast growing forest plantation timber species (Petit and Montagnini, 2004). Fast growing clonal eucalypts were introduced in Uganda from South Africa in 2002 by the National Forestry Resources Research Institute (NaFORRI) (Epila-Otara 2004). GC550, a hybrid of Eucalyptus grandis $\times$ camaldulensis is one of the of 12 eucalypt clones introduced in Uganda (Epila-Otara 2004

\footnotetext{
${ }^{1}$ Department of Forestry, Biodiversity and Tourism, Makerere University, Kampala, Uganda •Corresponding author: pkmugabi@gmail.com

Received: 09.01.2018 Accepted: 20.08.2018
} 
quoted by Turinawe et al. 2014) that has been widely adopted for transmission poles and fencing posts (Turinawe et al. 2014). However, because of the relatively high cost of the eucalypt clones, Phoenix reclinata has been used as an alternative to the eucalypts for fencing posts, especially in Central Uganda despite being a palm (Ssembajjwe et al. 2005). P. reclinata is a widely planted ornamental palm tree in tropical and subtropical regions. Although its wood is reported as durable and resistant to attacks by termites and fungi (Segu 2012), it has been observed to be easily attacked by termites in Uganda albeit this is not backed by scientific data since there is little information available. Yet untreated P. reclinata fencing posts continue to be used in central Uganda.

Euclyptus has been found to be highly susceptible to termite attack in different parts of Uganda (Ssemaganda et al. 2011, Nyeko and Olubayo 2005). According to Soderlund (2013), three sub families; Apicotermitinae, Macroermitinae and Termitinae were found to be existent in Uganda. In Tororo district in Eastern Uganda, Macrotermes bellicosus and M. subhyalinus were considered the most abundant termite species attacking the widest range of trees and crops, and causing the most damage (Nyeko and Olubayo 2005). Whereas Pseudacanthotermes militaris, Macrotermes subhyalinus, M. bellicosus, Nasutitermes arboreus and Eutermes arborum were reported to cause severe damage to pasture grass, trees and/or crops in Nakasongola district (Orikiriza et al. 2012) in Uganda.

According to Ssemaganda et al. (2011), some of the strategies to protect wood from termite attack include using naturally resistant tree species and or applying biocides. A range of different chemical treatments has been developed to enhance the durability and service life of timber. In addition to conventional wood preservatives such as creosote and waterborne preservatives, several authors (Pereira et al. 2015, Mattos et al. 2013, Ssemaganda et al. 2011) have reported use of used engine oil as an effective alternative to improve the biological resistance of wood in Uganda and Brazil. McKee and Plutin (1989) indicated that although fresh gasoline engine oil and both the fresh and used diesel engine oil were noncarcinogenic, majority of the used gasoline engine oils were carcinogenic and can, therefore, kill wood degrading agents in contact. According to Mattos et al. (2012), easy access of used engine oil from motor vehicles, its low cost and ease of application since pressure is not required, makes it suitable for preserving wood in rural areas by soaking or brushing. Some plant extracts have also been proved to be toxic and important in protection against termite damage. (Kadir 2017, Fatima and Morell 2015). For this study, the effectiveness of used engine oil in protecting fencing posts was investigated. Copper Chrome Arsenate (CCA) representing the conventional preservatives chemicals was used for bench marking purposes. The objectives of the study were to determine (i) the incidence and (ii) severity of termite attack on GC550 and P. reclinata fencing posts treated with CCA and used engine oil.

\section{MATERIALS AND METHODS}

\section{Timber}

Thirteen undebarked, defect free $P$. reclinata posts $2,1 \mathrm{~m}$ long and $8-10 \mathrm{~cm}$ in diameter, were randomly selected from Ndeeba, a Kampala suburb that harbors one of the largest market centers for this species and cross cut to 45 samples of $0,6 \mathrm{~m}$ length. Two defect free, 3 years old GC550 individual trees of Diameter at Breast Height (DBH) $10 \mathrm{~cm}$ were randomly selected and felled from a wood lot in Bukaleba, Mayuge District, $120 \mathrm{~km}$ east of Kampala. The trees were debarked and crosscut into 45 pieces of $0,6 \mathrm{~m}$ length. The $0,6 \mathrm{~m}$ long samples of both GC550 and P. reclinata were then air dried in ambient conditions until moisture content, measured by a moisture meter was $20 \%$ and then treated with CCA and used engine oil.

\section{Treatment of samples with preservatives}

Out of the 90 samples i.e. 45 for GC550 and 45 for $P$. reclinata, 15 samples of each species were treated with CCA by steeping for 2 days. The formulation of CCA used to treat the specimens comprised of copper oxide $(25,61 \%)$, chromium trioxide $(41,24 \%)$ and arsenic pentoxide $(33,15 \%)$, 
this was diluted to $4 \%$. Fourty liters of used engine oil was mixed with 12 liters of kerosene in an open drum in order to reduce the viscosity of engine oil and increase its penetration into the samples, then another 15 samples of each species were then submerged separately in the preservative for 2 days as well. The remaining 30 samples i.e. 15 for GC550 and 15 for $P$. reclinata were left untreated to act as control. The samples were then air dried and when the surfaces of the treated samples were dry enough for handling, they were transported to the field for exposure to termites.

\section{Study area description}

The field site was in Miroi village, Kolir Sub-County, Bukedea district in Eastern Uganda where a large infestation of termites had been detected earlier during the reconnaissance survey. It lies between the longitudes of $33^{\circ} 00 \mathrm{E} \& 33^{\circ} 45 \mathrm{E}$, and latitudes $33^{\circ} 00 \mathrm{E} \& 33^{\circ} 45 \mathrm{E}$, and an average altitude of 1800 meters above sea level. The District has a land Area of $2256,5 \mathrm{~km}^{2}$ of which water and swamps cover $406 \mathrm{~km}^{2}$. The main vegetation covering the district is wood land and grass savannah. Pinus carribea is the most common tree species planted in the district.

\section{Setup of the experiment}

The experiment was carried out in an enclosure to keep away grazing animals and people from tampering with the specimens. Ninety pits were dug at a spacing of $1 \mathrm{~m} \times 1 \mathrm{~m}$ and the samples were then buried in the pits with one foot height in the ground and the other one foot exposed. The samples were placed systematically in the order: CCA treated followed by the control and then the Engine oil treated sample (Figure 1).

\section{Data collection procedure}

Inspection of the samples was done every after 30 days for a period of 9 months starting from $28^{\text {th }}$ March, 2016 in order to monitor and evaluate the level of termite damage on the samples. At each time of inspection, specimens were removed from the ground and cleaned, and then the damage assessed. The incidence of termite attack was recorded as follows: A representing attacked and $\mathrm{N}$ represented not attacked. whereas the severity of the damage was recorded as follows: 1 representing less than $1 \%$ of total wood volume eaten; 2 for $1-20 \%$ of total wood volume eaten; 3 for $21-40 \%$; 4 for $41-60 \%$; and 5 representing above $60 \%$ of total wood volume eaten (Ssemaganda et al. 2011).

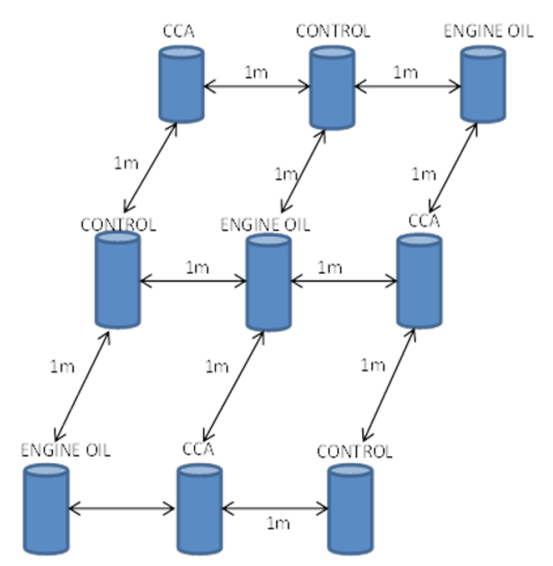

Figure 1: Arrangement of samples in the field. 


\section{Data analysis}

Descriptive statistics such as the modal incidence of attack, modal severity and the variations of termite damage on samples with different treatments were used.

\section{RESULTS AND DISCUSSION}

\section{Incidence of termite attack}

After one month of the experiment, none ( $0 \%$ ) of the treated samples of GC550 or P. reclinata were attacked while over $80 \%$ the untreated samples of both GC550 and P. reclinata had been attacked by termites (Figure 2). No CCA treated GC550 samples were attacked for 7 months and only $1(0,67 \%)$ sample had been attacked by end of the 9 months. However, attack on CCA treated $P$. reclinata samples commenced in the $5^{\text {th }}$ month and by the end of the experiment $20 \%$ of the samples had been attacked (Figure 2).The first engine oil treated GC550 sample was attacked in the $7^{\text {th }}$ month, with only 1 sample attacked by the end of the $9^{\text {th }}$ month. Similar to CCA, engine oil treated $P$. reclinata samples were first attacked in the $5^{\text {th }}$ month but $40 \%$ of these were attacked by the end of the experiment (Figure 2).

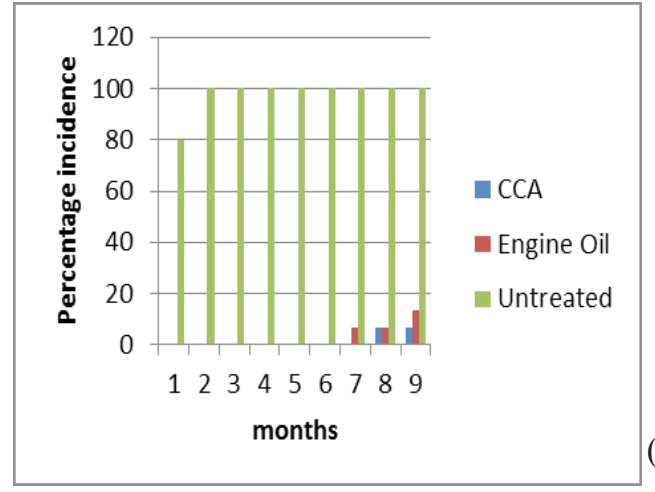

(a)

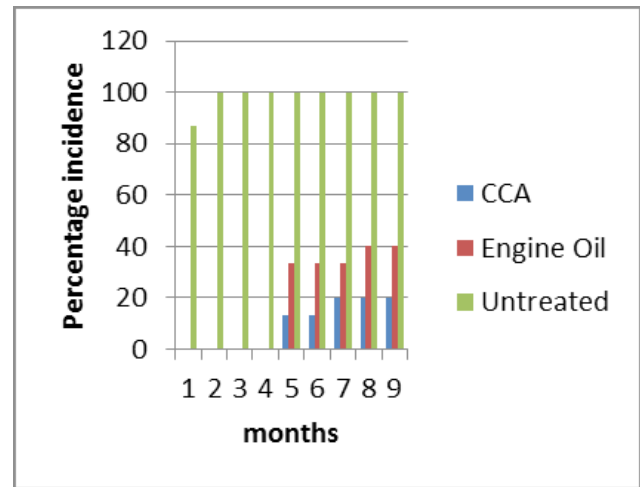

(b)

Figure 2: Percentage Incidence of termite attack on (a) GC550 and (b) P. reclinata for each month.

\section{Severity of termite attack}

For the entire period of the experiment i.e. 9 months, all samples of both GC550 and P. reclinata treated with CCA where still in class 1 . Whereas, GC550 samples treated with engine oil remained in class 1, P. reclinata samples were in severity class 2 by $7^{\text {th }}$ month (Figure 3 and Figure 4).

However, for the untreated samples, just after 1 month of the experiment $46,7 \%$ of the GC550 
samples were in already in severity class 3 (Figure 3 ). More than half $(53,3 \%)$ of the untreated $P$. reclinata samples, were in severity class 4 , just after one month. By the end of the experiment, 14 of the $15(93,3 \%)$ of untreated GC550 samples were in severity class 5 (Figure 3) while it took only 8 months for all the untreated $P$. reclinata samples to fall in class 5 of termite damage (Figure 4).

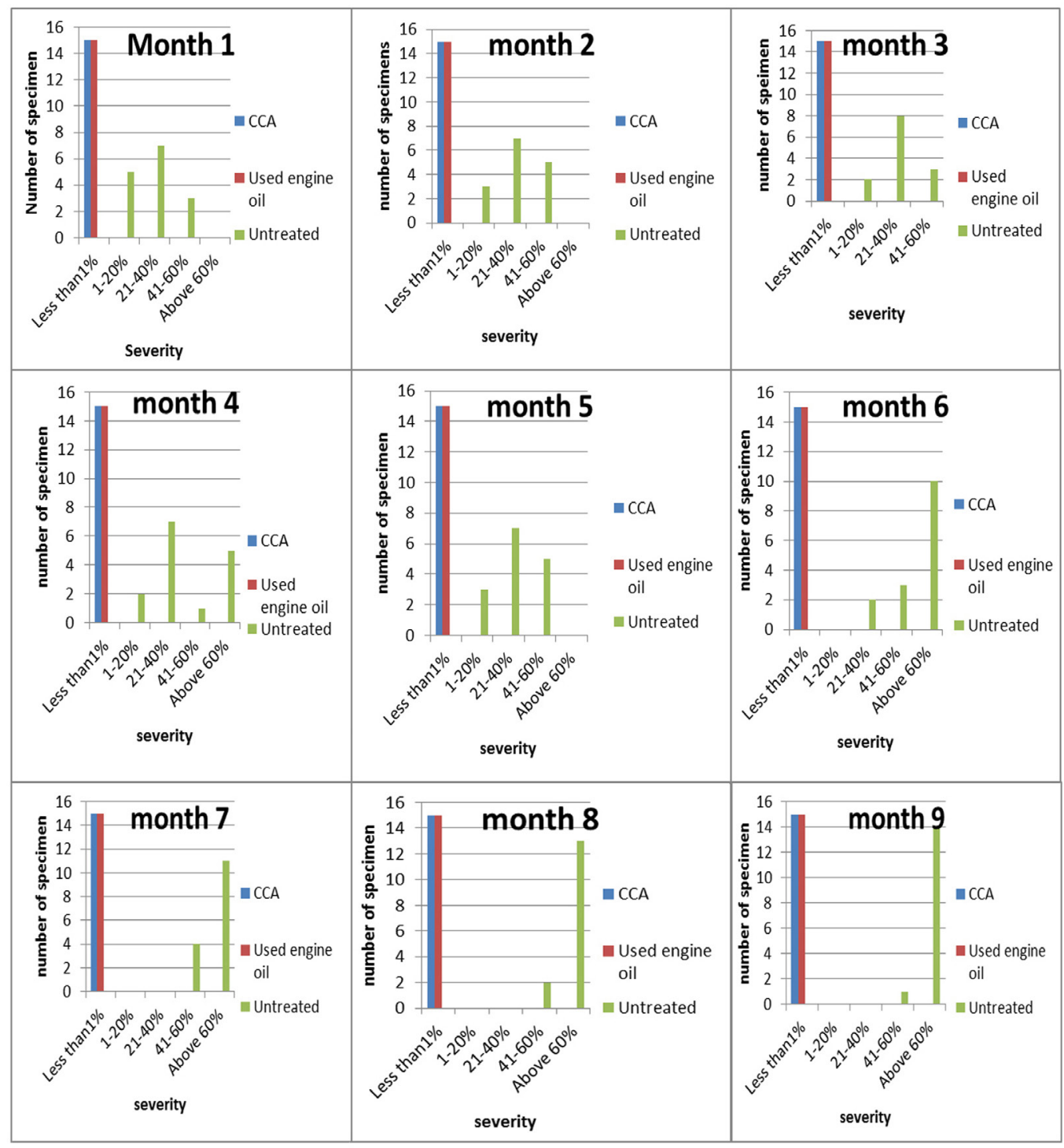

Figure 3: Number of GC550 samples treated with CCA and used engine oil in different severity classes at different months after establishment of the experiment. 


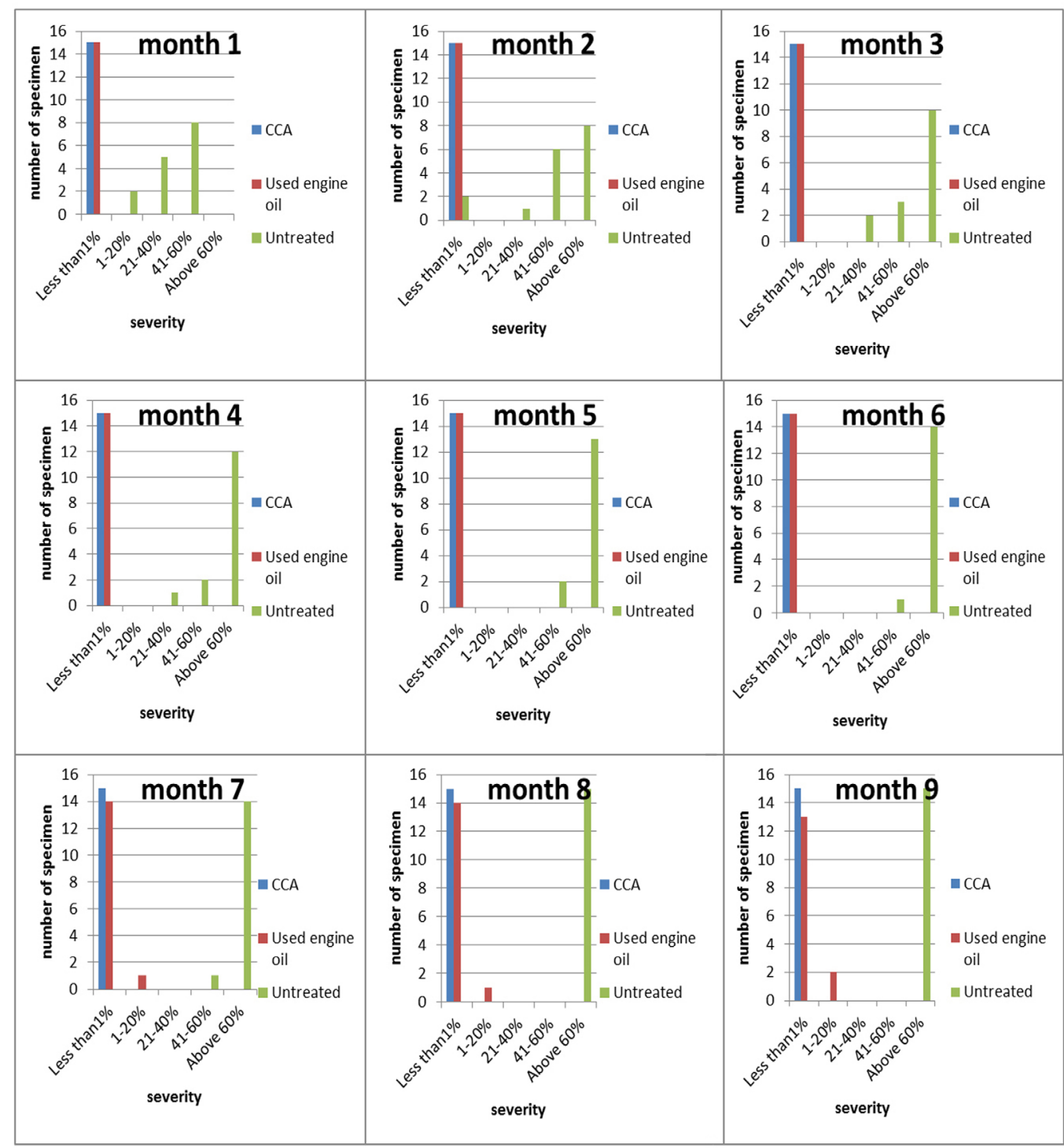

Figure 4: Number of $P$. reclinata samples treated with CCA and used engine oil in different severity classes at different months after establishment of the experiment.

\section{Modal severity of the samples}

The modal severity for GC550 and P. reclinata samples treated with either CCA or used engine oil was class 1 for the entire 9 months of field exposure. For untreated GC550 samples, for the first four months the modal severity was class 3 and class 5 for the rest of the remaining months (Table 1).The modal severity was class 4 for the first month and class 5 for rest of months in untreated $P$. reclinata samples. 
Table 1: Modal Severity of termite damage for all the samples.

\begin{tabular}{|c|l|l|l|l|l|l|l|l|l|l|}
\hline & \multicolumn{9}{|c|}{ Months } \\
\hline Treatment & Samples & $\mathbf{1}$ & $\mathbf{2}$ & $\mathbf{3}$ & $\mathbf{4}$ & $\mathbf{5}$ & $\mathbf{6}$ & $\mathbf{7}$ & $\mathbf{8}$ & $\mathbf{9}$ \\
\hline \multirow{3}{*}{ CCA } & GC550 & 1 & 1 & 1 & 1 & 1 & 1 & 1 & 1 & 1 \\
\cline { 2 - 13 } & Phoenix reclinata & 1 & 1 & 1 & 1 & 1 & 1 & 1 & 1 & 1 \\
\hline \multirow{2}{*}{$\begin{array}{c}\text { Used engine } \\
\text { oil }\end{array}$} & GC550 & 1 & 1 & 1 & 1 & 1 & 1 & 1 & 1 & 1 \\
\cline { 2 - 13 } & Phoenix reclinata & 1 & 1 & 1 & 1 & 1 & 1 & 1 & 1 & 1 \\
\hline \multirow{2}{*}{\begin{tabular}{c} 
Untreated \\
\cline { 2 - 13 }
\end{tabular}} & GC550 & 3 & 3 & 3 & 3 & 5 & 5 & 5 & 5 & 5 \\
\cline { 2 - 11 } & Phoenix reclinata & 4 & 5 & 5 & 5 & 5 & 5 & 5 & 5 & 5 \\
\hline
\end{tabular}

Key: 1,2,3,4 and 5 are severity classes representing less than $1 \%, 1-20 \%, 21-40 \%, 41-60 \%$ and above $60 \%$ respectively.

The fact that all the untreated samples of GC550 and P. reclinata were attacked by termites in the first month of the experiment shows that both of these species are highly susceptible to termite attack. For use in fencing, posts of the two species require preservative treatment yet the practice in Uganda is normally use of untreated posts. Untreated $P$. reclinata samples were marginally more susceptible to termite attack despite being preferred to eucalypts for fencing newly acquired land in Kampala. Even when treated with CCA or used engine oil, $P$. reclinata posts were still more susceptible to termite damage than GC550 treated with the same chemicals. Perhaps $P$. reclinata samples are softer and easier to tear by mandibles of worker termites compared to GC550 samples.

In GC550 samples, used engine oil was as good as CCA in giving protection against termites. At the end of the 9 months, all the GC550 samples treated with either used engine oil or CCA, were in severity class 1 (less than $1 \%$ of the total volume attacked) which is in agreement with Ssemaganda et al. (2011) but in $P$. reclinata, CCA was marginally better than engine oil over the 9 months. This is probably because CCA was able to penetrate better in $P$. reclinata samples than used engine oil.

\section{CONCLUSIONS}

Untreated posts of both GC550 and P. reclinata were highly susceptible to termite attack although the severity of the damage was marginally greater in the P. reclinata samples at the end of the experiment.

Treatment of GC550 samples with used engine oil or CCA delayed termite attack up to the 7 months but in $P$. reclinata both preservatives could only delay termite attack up to the $5^{\text {th }}$ month.

After 9 months, most of the treated posts of both species had only less than $1 \%$ of their total volume eaten by termites, for both preservatives.

And it is recommended that:

Posts of GC550 and P. reclinata should only be used when treated to extend their service life since they are highly susceptible to termite attack;

The mixture ratios, viscosity as well as retention and penetration in the two species be studied to establish the effect on the efficacy of the preservatives; poles;

The experiment be repeated for a much longer period in order to ascertain the service life of the

The same research be done on other Eucalyptus hybrid clones and other preservatives.

\section{ACKNOWLEDGEMENTS}

We appreciate the contribution of Busoga Forest Company in providing the samples used for this research. 


\section{REFERENCES}

Epila-Otara, J. 2004.Tree Biotechnology Project: Uganda's experience: In: Ngamau, C.; Kanyi, B.; Epila-Otara, J.; Mwangingo, P and Wakhusama, S., (Eds): Towards Optimizing the Benefits of Clonal Forestry to Small-scale Farmers in East Africa. International Service for the acquisition of AgriBiotechnology Applications (ISAA). Nairobi, Kenya. No. 33.

Fatima, R.; Morrell, J.J. 2015. Ability of plant-derived oils to inhibit dampwood termite (Zootermopsis augusticollis) activity. Maderas-Cienc Tecnol 17(3): 685-690.

Kadir, R. 2017. Toxic effects of three selected Malaysian timbers plant extracts against subterranean termites. Maderas-Cienc Tecnol 19(4): 417-432.

Mattos, B.D.; Gatto, D.A.; Missio, A.L.; Lourençon, T.V. 2012. Influência de Tratamentos preservativos na propagação da onda ultrassônicana madeira de eucalipto. Scientia Plena, São Cristóvão 8(4): 1-6.

Mattos, B.D; Gatto, D.A; Cademartori, P.H.G; Stangerlin, D.M.; Beltrame, R. 2013. Durabilidade a campo da madeira de três espécies de Eucalyptus tratadas por imersão simples. Revista Brasileira de Ciências Agrárias 8 (4): 648-655.

McKee, R.H.; Plutnick, R.T. 1989. Carcinogenic potential of gasoline and diesel engine oils Fundamental and Applied Toxicology 13 (3): 545-553.

Nyeko, P.; Olubayo, M.F. 2005. Participatory assessment of farmers' experiences of termite problems in agro forestry in Tororo district, Uganda. Agricultural research and extension network. Network paper No. 143. <www.odi.org.uk/publications>. (Consulted 24/05/2018).

Orikiriza, L.J.B.; Nyeko, P.; Sekamatte, B. 2012. Farmers' knowledge, perceptions and control of pestiferous termites in Nakasongola district, Uganda. Uganda Journal of Agricultural Sciences 13(1): $71-83$

Pereira, P.A.C.; Stangerlin, D.M.; Rodrigues de Andrade, V.; Rodrigues, D.A.; de Melo, R.R.; Corassa, J.N.; Calegari, L. 2015. Efficiency of used oil engine as preservative of Amazonian woods submitted to xylophagous termites. Ciência da Madeira 6(3): 176-182.

Petit, B.; Montagnini, F. 2004. Growth equations and rotation ages of ten native tree species in mixed and pure plantations in the humid neotropics. Forest Ecology and Management 199(2-3): 243257.

Ssemaganda, I.E.; Mugabi, P.; Tumwebaze, S.B. 2011. Effectiveness of selected preservatives in rotecting Ugandan grown Eucalyptus grandis wood against termite attack. Maderas-Cienc Tecnol 13(2): $135-142$.

Soderlund, S. 2013. Ants and termites in small-scale plantain farms in Uganda. A comparison between agroforestry and non-agroforestry farms. Bachelors thesis submitted to the Department of Ecology, Swedish University of Agricultural Sciences.

Segu, K. 2012. Phoenix reclinata jacq. In: Brink, M. and Achigan-Dako, E.G. (Eds.), Plant Resources of Tropical Africa 16 Fibres. PROTA Foundation: Wageningen, The Netherlands. ISBN $9789290814818-602$. pp.359-362

Ssembajjwe, G.; Banana,Y. A.; Bahati, J.; Namubiru, E.; Mukasa, C.; Waiswa, S.; Matovu, S. 2005. Mugomba Forest Reserve Site Report. Third Visit 2005. Forestry Resources and Institutions Center. Kampala Uganda.

Turinawe, H.; Mugabi, P.; Tweheyo, M. 2014. Density, calorific value and cleavage strength of selected hybrid eucalypts grown in Uganda. Maderas-Cienc Tecnol 16(1): 13-24. 